\title{
Pemphigus vulgaris as the first manifestation of multiple myeloma: a case report
}

Fandresena Arilala Sendrasoa*, Irina Mamisoa Ranaivo, Mendrika Fifaliana Rakotoarisaona, Onivola Raharolahy, Naina Harinjara Razanakoto, Malalaniaina Andrianarison, Lala Soavina Ramarozatovo and Fahafahantsoa Rapelanoro Rabenja

\begin{abstract}
Background: The association between pemphigus and malignancy has been well documented for decades but an association between pemphigus vulgaris and multiple myeloma is unusual. We report a case of pemphigus vulgaris revealing multiple myeloma.

Case presentation: A 55-year-old Malagasy man, with no significant past medical history, presented with bullous and erosive skin lesions involving his trunk and scalp for the last 2 months. He had no mucous membrane involvement. A diagnosis of pemphigus vulgaris was made on skin biopsy and direct immunofluorescence of perilesional skin revealing immunoglobulin $\mathrm{G}$ deposition in the intercellular spaces in the epidermis. In an enzyme-linked immunosorbent assay, his serum autoantibody index against desmoglein-1 and 3 was found to be $112 \mathrm{RU} / \mathrm{mL}$ and 34 $\mathrm{RU} / \mathrm{mL}$ respectively. Serum immunoelectrophoresis showed a monoclonal gammopathy with a markedly elevated immunoglobulin $\mathrm{G}$ level $(2880 \mathrm{mg} / \mathrm{dL})$ in association with a lambda free light chain. Bone marrow aspirate showed 6\% plasma cell infiltration. Further investigations, including creatinine blood test and whole body radiographic examinations, showed that he had initially clinical stage I multiple myeloma of the immunoglobulin $G-\lambda$ type. Six months later, bone tomography revealed vertebral compression fractures of the thoracic and lumbar spine that correlated with his back pain topographically. Anti-myeloma treatment including melphalan and prednisone led to an immediate decline in monoclonal immunoglobulin G concentration. Skin and hematologic remission were maintained for 12 months.
\end{abstract}

Conclusions: Absence of mucosal involvement, lack of vacuolar degeneration at the interface, and absence of apoptotic, dyskeratotic keratinocytes ruled out paraneoplastic pemphigus in our case. Pemphigus vulgaris should be considered even if possible underlying disease for which paraneoplastic pemphigus is recognized is present.

Keywords: Pemphigus vulgaris, Multiple myeloma, Skin, Remission

\section{Background}

Pemphigus is a group of chronic blistering disorders of the skin and mucosal membranes caused by autoantibodies against epithelial cell adhesion molecules. The association between pemphigus and malignancy has been well known for decades [1] but the association between pemphigus vulgaris (PV) and multiple myeloma is unusual. We report a case of PV revealing multiple myeloma, in which the clinical features and results of

\footnotetext{
* Correspondence: nasendrefa@yahoo.fr

Department of Dermatology, University Hospital Joseph Raseta Befelatanana, Antananarivo, Madagascar
}

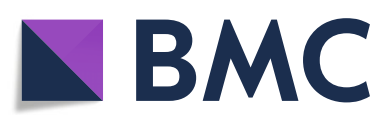

(c) The Author(s). 2018 Open Access This article is distributed under the terms of the Creative Commons Attribution 4.0 International License (http://creativecommons.org/licenses/by/4.0/), which permits unrestricted use, distribution, and reproduction in any medium, provided you give appropriate credit to the original author(s) and the source, provide a link to the Creative Commons license, and indicate if changes were made. The Creative Commons Public Domain Dedication waiver (http://creativecommons.org/publicdomain/zero/1.0/) applies to the data made available in this article, unless otherwise stated. immunoserological examinations were not characteristic of paraneoplastic pemphigus (PNP).

\section{Case presentation}

A 55-year-old Malagasy man, a doctor, a non-smoker of tobacco, with no significant past medical history, presented with bullous and erosive skin lesions involving his trunk and scalp for the past 2 months. No toxic exposure was noted. He had a family history of cancer; his mother and sister presented breast cancer and multiple myeloma, respectively, the diagnosis of which were delayed. He had no personal or family history of any autoimmune 
disease. No medication was prescribed prior to diagnosis. A physical examination revealed multiple crusted erosions intermixed with erythematosus patches over his scalp (Fig. 1), trunk (Fig. 2a), and his back (Fig. 2b). He had no mucous membrane involvement. General physical and systemic examinations were normal.

A complete blood count revealed microcytosis without anemia with mean corpuscular volume (MCV) of $76 \mathrm{fl}$ and hemoglobin of $15.7 \mathrm{~g} / \mathrm{dL}$; his white cell count and platelet count were normal. Alanine and aspartate aminotransferase were normal ( $28 \mathrm{U} / \mathrm{L}$ and $25 \mathrm{U} / \mathrm{L}$, respectively) but serum creatinine was high (121 umol/l; normal range: 53-115 umol/L). Other laboratory tests including corrected calcium level, phosphoremia, lactate dehydrogenase, and urine analysis were normal. His HIV status was negative.

A skin biopsy showed suprabasal blisters containing eosinophils and acantholytic keratinocytes. Direct immunofluorescence of perilesional skin revealed immunoglobulin G (IgG) deposition in the intercellular spaces in the epidermis. In an enzyme-linked immunosorbent assay (ELISA), his serum autoantibody index against desmoglein-1 and 3 was found to be $112 \mathrm{RU} / \mathrm{mL}$ and $34 \mathrm{RU} / \mathrm{mL}$ (normal range, $<20 \mathrm{RU} / \mathrm{mL}$ ), respectively. Serum immunoelectrophoresis showed a monoclonal gammopathy with a markedly elevated IgG level $(2880 \mathrm{mg} / \mathrm{dL})$ in association with a lambda free light chain. Urine analysis was negative for Bence-Jones protein and beta2-microglobulin was $2.4 \mathrm{mg} / \mathrm{L}$. Bone marrow aspirate showed $6 \%$ plasma cell infiltration. Further investigations, including creatinine blood test and whole body radiographic examinations, showed that he had clinical stage I multiple myeloma of the IgG- $\lambda$ type.

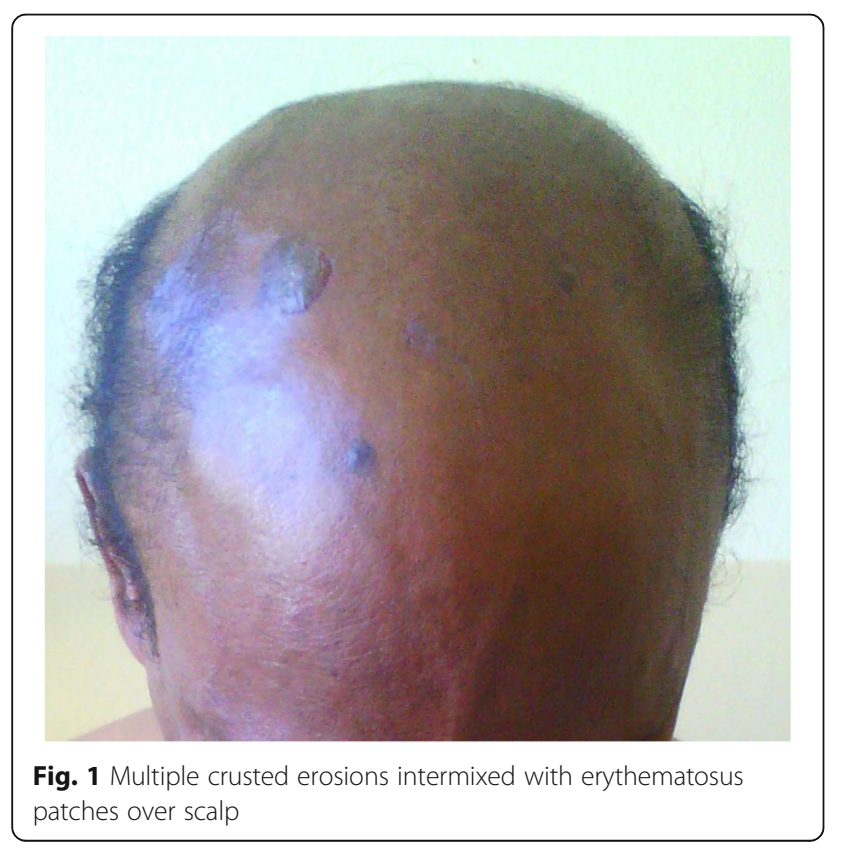

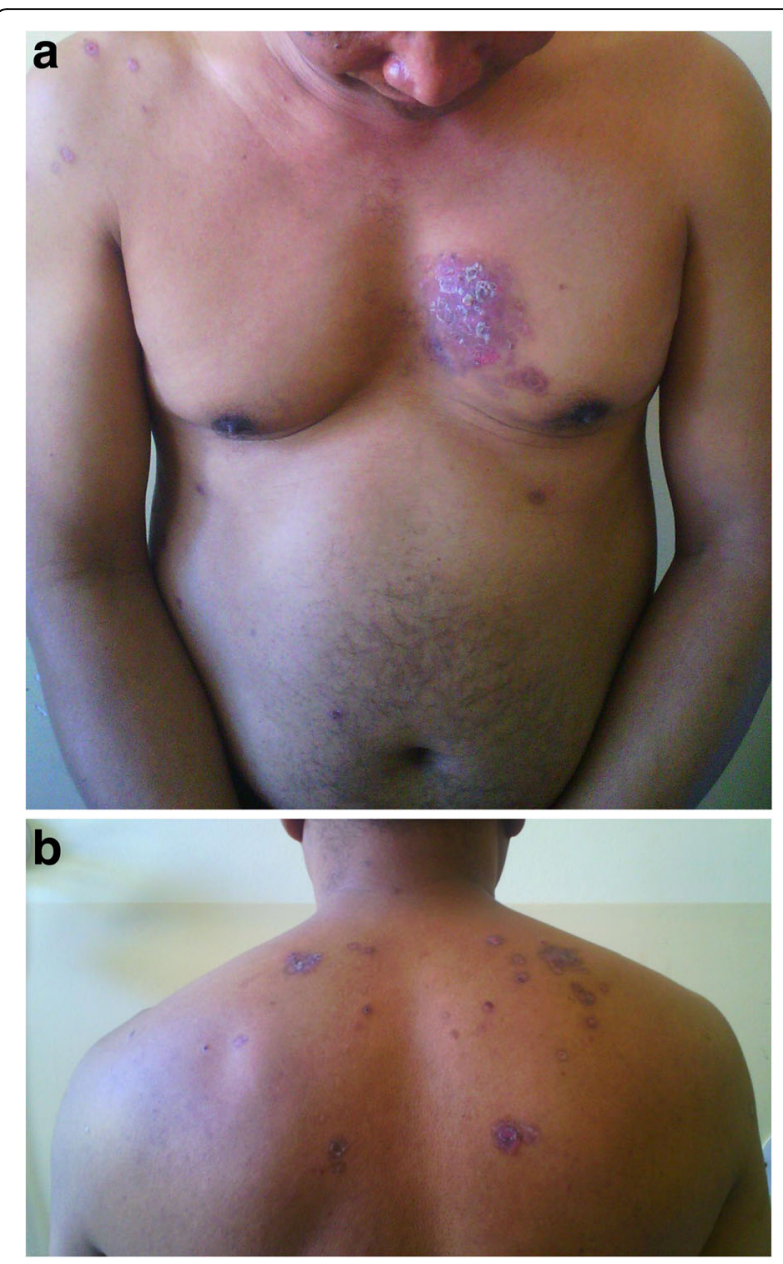

Fig. 2 a Multiple crusted erosions intermixed with erythematosus patches over trunk. b Multiple crusted erosions intermixed with erythematosus patches over the back

At first, the skin lesions regressed significantly after topical applications of corticosteroid ointment and no specific therapy for myeloma was conducted. Three months later, the dermal affliction occurred again so systemic administration of prednisolone $(1 \mathrm{mg} / \mathrm{kg}$ per day) was started. Six months later, bone tomography revealed vertebral compression fractures of the thoracic and lumbar spine that correlated with our patient's back pain topographically. However, his IgG level decreased $(1080 \mathrm{mg} / \mathrm{dL})$. Anti-myeloma treatment including melphalan and prednisone was started, which resulted in a rapid decline of monoclonal IgG concentration immediately. Skin and hematologic remission were maintained for 12 months.

\section{Discussion}

Considering the results of routine microscopic sections, immunohistopathological examinations, and immunoserological analysis, our case definitely has PV but not 
Table 1 Salient features to differentiate between pemphigus vulgaris and paraneoplastic pemphigus

\begin{tabular}{|c|c|c|}
\hline & Pemphigus vulgaris & Pemphigus paraneoplastic \\
\hline Clinical findings & $\begin{array}{l}\text { - Oral erosions particularly on the labial and } \\
\text { buccal mucosa }\end{array}$ & $\begin{array}{l}\text { - Painful, progressive stomatitis involving the tongue } \\
\text { - Blisters and targetoid lesions on the palms and soles }\end{array}$ \\
\hline Direct immunofluorescence & $\begin{array}{l}\text { - Intercellular deposition of lgG and C3 in } \\
\text { "chicken-wire" lattice pattern }\end{array}$ & $\begin{array}{l}\text { - IgG deposition in all layers of the epidermidis and } \\
\text { C3 in the lower epidermis and basement membrane } \\
\text { - Intercellular staining is focal and faint }\end{array}$ \\
\hline Autoantibodies & $\begin{array}{l}\text { - Autoantibodies against desmoglein-1 } \\
\text { and desmoglein-3 }\end{array}$ & $\begin{array}{l}\text { - Autoantibodies against desmoglein-1 and desmoglein-3 } \\
\text { - Autoantibodies against proteins in the plakin family } \\
\text { (plectin, desmoplakin I, desmoplakin II, bullous pemphigoid } \\
\text { antigen I, envoplakin, and periplakin) }\end{array}$ \\
\hline Visceral involvement & - Very rare & $\begin{array}{l}\text { - Mucous membranes of the esophagus, stomach, } \\
\text { duodenum, intestines, and pulmonary epithelium }\end{array}$ \\
\hline
\end{tabular}

$\lg$ G immunoglobulin G

PNP which is known to be associated with multiple myeloma. To the best of our knowledge, there have been no reported cases of multiple myeloma revealed by PV in Madagascar.

Skin lesions are frequently encountered in clinical practice; they can be a presentation of systemic diseases not excluding an occult malignancy. The association of pemphigus with malignancy has been well documented [2, 3]. PNP, a new disease entity, was first described by Anhalt et al. in 1990 [4]; PNP is associated primarily with malignant and benign tumors of hematological tissue origin. However, PV associated with multiple myeloma is rare. Kridin et al. reported 16 cases of multiple myeloma in 1985 patients with pemphigus [5]. Absence of mucosal involvement, lack of vacuolar degeneration at the interface, and absence of apoptotic, dyskeratotic keratinocytes ruled out PNP in our case. Furthermore, our patient's skin lesion was not as severe or as polymorphous as those in PNP. PV and PNP have similar clinical presentations but have different pathophysiologies in that PV shows a more favorable prognosis than PNP, which often leads to pulmonary involvement. PNP is known to associate with diverse conditions such as non-Hodgkin's lymphoma, chronic lymphocytic leukemia, Castleman's disease, thymoma, and Waldenstrom's macroglobulinemia; however, PV should be considered even if the possible underlying diseases for which PNP is recognized are present. Table 1 shows salient features to differentiate between PV and PNP.

Scleromyxedema, lichen myxedematosus, and papular mucinosis are the skin disorders most associated with monoclonal gammopathy [6, 7]. PV concomitant with multiple myeloma was first reported by Motoki Kurokawa et al. in 2005 [8]. Furthermore, there are several reports of cases of myeloma associated with autoimmune diseases such as autoimmune hemolytic anemia [9], acquired von Willebrand disease [10], Sjögren's syndrome [11], and Hashimoto's thyroiditis [12]. Although multiple myeloma is basically a B cell malignancy, the mechanism of autoantibody production in myeloma is still unclear. Fas mutations have been found in multiple myeloma, and there is a high incidence of autoreactive phenomena in patients with Fas mutations, such as systemic lupus erythematosus, Sjögren's syndrome, and Hashimoto's thyroiditis.

\section{Conclusions}

Our patient's case illustrates an uncommon occurrence of PV and multiple myeloma, presumably the first reported case in Madagascar. PV should be considered even if possible underlying disease for which PNP is recognized is present.

\section{Abbreviations}

ELISA: Enzyme-linked immunosorbent assay; MCV: Mean corpuscular volume; PNP: Paraneoplastic pemphigus; PV: Pemphigus vulgaris

\section{Acknowledgements}

This work is original and has not been published elsewhere nor is it currently under consideration for publication elsewhere.

\section{Authors' contributions}

The authors were involved in the writing of the manuscript or patient clinical care. All authors read and approved the final manuscript.

Ethics approval and consent to participate Not applicable.

\section{Consent for publication}

Written informed consent was obtained from the patient for publication of this case report and any accompanying images. A copy of the written consent is available for review by the Editor-in-Chief of this journal.

\section{Competing interests}

The authors declare that they have no competing interests.

\section{Publisher's Note}

Springer Nature remains neutral with regard to jurisdictional claims in published maps and institutional affiliations.

Received: 15 February 2018 Accepted: 3 August 2018

Published online: 07 September 2018

References

1. Krain LS, Bierman SM. Pemphigus vulgaris and internal malignancy. Cancer. 1974;33:1091-9.

2. Schulze F, Neumann $K$, Recke A, Zillikens D, Linder R, Schmidt E. Malignancies in pemphigus and pemphigoid diseases. J Invest Dermatol. 2015;135:1445-7.

3. Saraya T, Fujiwara M, Shimura C, Goto H. Not paraneoplastic pemphigus but pemphigus vulgaris in a patient with thymoma. BMJ Case Rep. 2015; https://doi.org/10.1136/bcr-2015-210433. 
4. Anhalt GJ, Kim SC, Stanley JR, Korman NJ, Jabs DA, Kory M, et al. Paraneoplastic pemphigus: an autoimmune mucocutaneous disease associated with neoplasia. N Engl J Med. 1990;323(25):1729-35.

5. Kridin K, Zelber-Sagi S, Comaneshter D, Batat E, Arnon D, Cohen A.

Pemphigus and hematologic malignancies: a population-based study of 11,859 patients. J Am Acad Dermatol. 2018;78(6):1084-9.

6. Harati A, Brockmeyer NH, Altmeyer P, et al. Skin disorders in association with monoclonal gammopathies. Eur J Med Res. 2005;10:93-104.

7. Donato ML, Feasel AM, Weber DM, et al. Scleromyxedema: role of highdose melphalan with autologous stem cell transplantation. Blood. 2006; 107:463-6.

8. Kurokawa M, Koketsu H, Oda Y, Nagamine H, Toyama T, Hashimoto T, Setoyama M. A case of pemphigus vulgaris accompanied by multiple myeloma. Int J Dermatol. 2005;44:873-5.

9. Vaiopoulos G, Kyriakou D, Papadaki H, et al. Multiple myeloma associated with autoimmune hemolytic anemia. Haematologica. 1994;79:262-4.

10. Mohri H, Tanabe J, Ohtsuka M, et al. Acquired von Willebrand disease associated with multiple myeloma; characterization of an inhibitor to von Willebrand factor. Blood Coagul Fibrinolysis. 1995;6:561-6.

11. Terpos E, Angelopoulou MK, Variami E, et al. Sjogren's syndrome associated with multiple myeloma. Ann Hematol. 2000;79:449-51.

12. Wu MJ, Fang HC, Chang TY, et al. Multiple myeloma with myeloma nephropathy in a patient with Hashimoto's thyroiditis. J Formos Med Assoc. 2002;101:421-4.

Ready to submit your research? Choose BMC and benefit from:

- fast, convenient online submission

- thorough peer review by experienced researchers in your field

- rapid publication on acceptance

- support for research data, including large and complex data types

- gold Open Access which fosters wider collaboration and increased citations

- maximum visibility for your research: over $100 \mathrm{M}$ website views per year

At $\mathrm{BMC}$, research is always in progress.

Learn more biomedcentral.com/submissions 